\title{
Effect of packaging material and postharvest calcium treatment on weight loss, decay and biochemical quality of strawberry fruits during storage
}

\section{Rakesh Kumar*}

Krishi Vigyan Kendra-National Horticultural Research and Development Foundation, Ujwa, New Delhi - 110073, India; Amity Institute of Horticulture Studies and Research, Amity University, Noida 201313 (Uttar Pradesh), India

\section{R. S. Antil}

Amity Institute of Horticulture Studies and Research, Amity University, Noida - 201313 (Uttar Pradesh), India

\section{Angrej Ali}

Sher-e-Kashmir University of Agricultural Sciences and Technology of Kashmir, Wadura Campus, Sopore - 193201 (J \& K), India

${ }^{*}$ Corresponding author. Email: rakesh4565k@gmail.com

\section{Article Info}

https://doi.org/10.31018/

jans.v13i4.2981

Received: August 28, 2021

Revised: October 13, 2021

Accepted: October 21, 2021

\section{How to Cite}

Kumar, R. et al. (2021). Effect of packaging material and postharvest calcium treatment on weight loss, decay and biochemical quality of strawberry fruits during storage. Journal of Applied and Natural Science, 13(4), 1158 - 1165. https://doi.org/1 0.31018/jans.v13i4.2981

\begin{abstract}
Strawberry (Fragaria $\mathrm{x}$ ananassa Duch.) fruits are highly perishable which lose their marketability within a short period of time, resulting in considerable loss of fruits after harvest. In present study, the packaging materials treatment i.e. polypropylene terephthalate (PET) Punnet and High density polythene (HDPE) crates and calcium compounds $\left(\mathrm{CaCl}_{2}\right.$ and $\left.\mathrm{Ca}\left(\mathrm{No}_{3}\right)_{2}\right)$ were examined for the storability and biochemical quality of strawberry (cv. Winter Down) fruits in cold condition $\left(3 \pm 1^{\circ} \mathrm{C}\right.$ ) in comparison to the untreated control fruit in ambient storage for 3, 6 and 8 days storage period. Results revealed that physiological loss in weight $(\mathrm{PLW})$ and fruit decay increased with the advancement of the storage period irrespective of the treatments. Fruits treated with $\mathrm{CaCl}_{2}(2 \%)$, packed in PET Punnets and stored in cold condition $\left(3 \pm 1^{\circ} \mathrm{C}\right)$ showed significantly minimum PLW $(6.55,11.12$ and $1534 \%)$ and fruit decay $(7.29,17.71$ and $34.38 \%)$ at 3,6 and 8 days storage, respectively. Non-treated control fruits at ambient conditions could not maintain their marketability even 3 days of storage and showed relatively high decay losses $(25.00,62.21$ and $91.67 \%$ at 3,6 and 8 days of storage, respectively). Packaging and calcium treatment did not affect the fruit total soluble solids (TSS) and total sugars but was found effective to slow down the decrease of ascorbic acid and acidity contents of the fruit during storage. PET Punnets packaged fruits treated with $\mathrm{CaCl}_{2}(2 \%)$ under cold conditions retained better shelf -life with better biochemical quality of fruits during storage while untreated control fruits deteriorated rapidly.
\end{abstract}

Keywords: Calcium, Fragaria $\times$ ananssa Duch., Fruit quality, Packaging, Physiological loss in weight, Storability

\section{INTRODUCTION}

Strawberry (Fragaria $\mathrm{x}$ ananassa Duch., Family Rosaceae, subfamily Rosoideae) is herbaceous perennial of temperate origin (Potter et al., 2000) and commercially cultivated in a broad range of climates, including temperate, Mediterranean, and subtropical regions of the world (Hancock, 2008). Strawberry fruits are prized for their delectable taste, health-promoting properties, and reputation as the "Harbinger of Spring" (Wilhelm and Sagen, 1974). It is one of the most adorable fruits, often characterized by its unique organoleptic properties, nutritional values, flavonoids and diverse array of phenolic compounds (Giampieri et al., 2012). In India, strawberry performs equally well in climates that are characteristically temperate in the northern latitudes, sub-tropical in the plains, or tropical at high altitude (Pramanick et al., 2013). Temperate regions of Northern India viz., Jammu and Kashmir, Himachal Pradesh and Uttrakhand have been traditional states of commercial strawberry cultivation; however, cultivation in subtropical and tropical plains have gained momentum in the last few decades. Although, the extreme summer temperatures in the plains region 
restricts the longer cropping season and runner production are very low (Ali and Gaur, 2013); farmers in Delhi, Haryana, Punjab, Maharashtra, Karnataka, and Uttar Pradesh obtain planting materials from hill states and produce strawberries profitably during the cold months and in spring season in open field condition. A number of large-fruited, high yielding varieties, introduced in temperate regions of India from Europe and North America such as Chandler, Sweet Charlie, Pajaro, Etna, Selva, Douglas, Confictura, Dana, Belrubi, Gorella, and Addie, etc., are also being explored in plains of the country. In recent past, strawberry has received impetus with large business houses setting up a number of agro-based establishments primarily aimed at large scale production of strawberry fruits for super markets in metro-cities (Pramanick et al., 2013).

Strawberry is a highly perishable non-climacteric fruit and not advisable for storage even for a week under ambient conditions. Fruits continue to increase in size during the ripening process (Perkins-Veazie and Huber, 1987; Abeles and Takeda, 1990; Perkins-Veazie et al., 2008). The physiological, morphological, and compositional changes concurrent during fruit ripening and the entire ripening process is rapid, generally occurring within 5 to 10 days following the white stage to red colour fruits and highly depends on air temperature (Kano and Asahira, 1981; Perkins-Veazie et al., 1987). Fruit softening occurs due to disassembly of the cell wall as a result of the dissolution of middle lamellae during ripening (Paniagua, et al., 2014). Fruits exhibit high respiration and tissue softening rate, water loss and susceptibility to physical damage during postharvest handling (Kader, 1991, Kader, 1999). Relatively high postharvest losses of fruits occur due to fungal development, mechanical injury, physiological deterioration and water loss (Cordenunsi et al., 2005). Fruit maturity, packaging method, and transportation distance greatly influence the post-harvest losses in strawberries (Duran et al., 2016; Matar, et al., 2020). Therefore, developing and carefully adhering to specific postharvest management techniques of strawberries are critical to ensuring fruit quality for a longer duration. Postharvest rapid cooling and storage at low temperature $\left(0-4{ }^{\circ} \mathrm{C}\right)$ is the most effective method for maintaining strawberry fruit quality (Tahir et al, 2018); however, assuring proper storage and temperature control during the transportation chain is not always possible in India due to limited refrigerated transport chain facilities. Hence, appropriate postharvest treatments are crucial to limit the rate of respiration and water loss, maintain fruit firmness, and reduce pathogen development under ambient and cold storage settings. One of the low-cost techniques to increase the shelf life of soft fruits is modified atmospheric packaging (MAP) using different films or packaging materials (Gorris et al. 1992; Moyls et al., 1996; Van-
der-Steen et al., 2002; Sandhya, 2010; Opara et al., 1919) with its well-known benefits of maintaining the freshness of fruits comparatively for an extended period. According to Smith (1992), strawberry packed with PP punnets develops as an internal atmosphere with gaseous composition recommended for strawberry. Nielsen and Leufven (2008) also advocated the modified atmospheric packaging for enhancing the storability and fruit quality. Various kinds of synthetic chemicals also have been utilized to increase postharvest life; however, their uses are highly restricted due to food safety issues. The use of calcium compounds has been reported beneficial in maintaining the quality of several fruits during storage. Localized calcium deficiency can be attributed to differences in xylem morphology, amniotic fluid conditions, and pectin composition and leads to leaky membranes, irregular cell migration, the transmission of altered hormonal signals and abnormal development of the fruit (Hocking et at., 2016). Increased calcium content in fruit tissue cell walls can assist in postponing softening and mould growth and reducing the occurrence of physiological problems (Rosen and Kader, 1989; Garcia et al., 1996). A higher concentration of cell wall-associated calcium in the firmer fruit suggests that there is a pectin calcium and hemicellulose dynamic associated with contrasting firmness at harvest and during cold storage (Olmedo et al., 2021). Calcium is a divalent cation that readily enters the apoplast and is bound to the cell wall and exterior surface of the plasma membrane in an exchangeable form and maintains the cell wall structure of the fruit by interacting with the pectic acid in the cell walls to form calcium pectate (White, 2001; Hocking et al., 2016). $\mathrm{Ca}^{2+}$ forms cross-links between pairs of negatively charged homogalacturonans, thus tightening the cell wall (Picchioni et al., 1998). According to Dunn and Able (2005), the application of calcium delayed fruit ripening and the development of grey mould and resulted in better quality fruits in strawberry. The present study intended to assess the combined response of packaging material and calcium compounds and on shelf life and the fruit quality attributes of strawberry (Fragaria $\mathrm{x}$ ananassa Duch.) during storage.

\section{MATERIALS AND METHODS}

The present study was conducted at Krishi Vigyan Kendra (NHRDF), Ujwa, New Delhi, during 2018-19. Strawberry (Fragaria $\mathrm{x}$ ananassa Duch.) cv. Winter Down fruits were manually harvested at the red ripe stage of maturity. The fruits were selected for color and size, individually picked in plastic trays and immediately transferred to the laboratory and kept for $30 \mathrm{~min}$ to remove field heat under ambient conditions. Uniform size fruits were selected and seven lots were taken for the 
treatments, each consisted of 48 fruits with four replicates. One another fruit lot was also used for initial recording data on physio-chemical parameters. Fruits were gently washed with distilled water and allowed to dry under a drier fan for 30 minutes and thereafter subjected to packaging and calcium treatments. Treatments consisted of $\left(T_{1}\right)$ Calcium chloride @ $2 \%$ + polypropylene terephthalate (PET) packaging, $\left(\mathrm{T}_{2}\right)$ Calcium nitrate @ $1.5 \%$ + PET packaging, $\left(\mathrm{T}_{3}\right)$ PET packaging, $\left(\mathrm{T}_{4}\right)$ Calcium chloride @ $2 \%$ + High-density polythene (HDPE) crates, $\left(T_{5}\right)$ Calcium nitrate @ $1.5 \%$ + HDPE crates, $\left(T_{6}\right)$ HDPE crates, and $\left(T_{7}\right)$ untreated control. A quick dip method was used for treating fruits with calcium chloride and calcium nitrate. After treatment, again, fruits were dried under fan drier for 30 minutes before packing. Untreated control fruits were kept in a ventilated room at ambient conditions $\left(26^{\circ} \mathrm{C} \pm 3{ }^{\circ} \mathrm{C}\right)$ while the remaining set of treatments were stored in Refrigerator $\left(3{ }^{\circ} \mathrm{C} \pm 1{ }^{\circ} \mathrm{C}\right)$. The experiment was laid out in randomized complete block design (RCBD) with four replications.

\section{Fruit quality assessment}

Observations on physiological loss in weight (PLW) and decay percentage were recorded at 3, 6 and 8 days of storage, while biochemical quality of fruit (titratable acidity, total soluble solids, total sugars, and ascorbic acid content) were recorded $0,3,6$ and 8 days of storage in accordance of the procedures given hereunder:

\section{Physiological loss in weight}

Physiological loss in weight of the fruit was determined by the formula suggested by Westwood (1979). The PLW of the fruits in per cent was calculated on initial weight and final weight noted on specified days after storage using the following formula:

PLW $(\%)=($ Initial weight - Final weight $) /$ Initial weight $\mathrm{x} 100$ Eq. 1

\section{Fruit decay}

The Fruit decay was calculated by subtracting the number of decay fruit from the total number of fruits in each treatment on specified days after storage using following formula and expressed in per cent.

Decay $(\%)=($ Total number of fruits - Number of decay fruits)/Total number of fruits $\times 100$ Eq. 2

\section{Biochemical quality of fruit}

Total soluble solid (TSS) was determined by Hand Refractometer (0-32 ${ }^{\circ}$ Brix). Titratable acidity was determined by titrating juice against standard alkali solution using phenolphthalein as indicator, ascorbic acid was determined by 2,6-dichlorophenol indophenol visual titration method and total sugars was determined using Fehling's solutions (AOAC, 2019).

\section{Statistical analysis}

The data were analyzed according to the procedure for analysis of Randomized Complete Block Design (Gomez and Gomez, 1984). The results were statistically analyzed with the help of using SPSS software package 10 . The significance of difference among the treatments mean was tested at $5 \%$ level of significance using the critical differences (CD).

\section{RESULTS AND DISCUSSION}

\section{Physiological loss in weight (\%)}

Physiological loss in weight (PLW) of fruit was increased with the advancement of storage duration, irrespective of the treatments; although, fruits treated with packaging materials and calcium compounds showed significantly low PLW as compared to untreated control (Table 1). At 3 days storage, $\mathrm{CaCl}_{2}$ (2\%) treated fruits packed in PET Punnets resulted in the minimum PLW (6.55\%) under cold storage $\left(3^{\circ} \mathrm{C} \pm 1{ }^{\circ} \mathrm{C}\right)$ while the maximum PLW (13.54\%) was observed in control fruits stored at ambient conditions $\left(26^{\circ} \mathrm{C} \pm 3{ }^{\circ} \mathrm{C}\right)$. Similar observation with regards to PLW under different treatments was observed at 6 and 8 days of storage, wherein minimum PLW was observed in the $\mathrm{CaCl}_{2}$ (2\%) treated fruits packed in PET Punnets (11.12 and $15.34 \%$ ) and the maximum physiological loss was observed in control (23.50 and $32.46 \%$ ) at 6 and 8 days of storage, respectively. Weight loss of fruit is one of the most noticeable changes in strawberries during storage, and it is linked to changes in metabolism and water content (Garcia et al., 2011). Packaging materials alter the $\mathrm{CO}_{2}$ and $\mathrm{O}_{2}$ ratios inside the packages; the respiration rate of such a high respiring fruit like a strawberry is lowered by confining it in a low $\mathrm{O}_{2}$ and/or high $\mathrm{CO}_{2}$ state (El-Kazzaz et al., 1983). Khalid et al., (2020) also observed that packaging material significantly influenced mass loss (\%) of strawberry, wherein maximum mass loss $(9.11 \%)$ was recorded in control samples while minimum mass loss $(1.24 \%)$ in polyethylene enclosed fruit. Fruits packaged with various packaging films lose less weight and appropriately play their role in regulating the rate of transpiration/ respiration. High respiration and transpiration rates, high temperature, enhanced microbial infection, and elevated catabolic activity of strawberry fruits are all factors that contribute to greater PLW in the control fruits (Shin et al., 2008; Jouki and Khazaei, 2012).

\section{Decay loss (\%)}

Fruit decay increased as the storage time progressed; however, calcium compounds and packaging treatments showed a significant role in minimizing the fruit decay loss (Table 2). At 3 days of cold storage, fruit treated with $\mathrm{CaCl}_{2}(2 \%)$ and packed in PET Punnets 
Table 1. Effect of packaging materials and post-harvest calcium treatment on physiological loss in weight of strawberry fruits during storage

\begin{tabular}{llll}
\hline \multirow{2}{*}{ Treatment } & \multicolumn{3}{c}{ Physiological loss in weight (\%) } \\
\cline { 2 - 4 } & 3 DAS & 6 DAS & 8 DS \\
\hline $\mathrm{T}_{1}$-PET Punnets $+\mathrm{CaCl}_{2}(2 \%)$ & 6.55 & 11.12 & 15.34 \\
$\mathrm{~T}_{2}$-PET Punnets $+\mathrm{Ca}\left(\mathrm{NO}_{3}\right)_{2}(1.5 \%)$ & 7.40 & 12.48 & 17.35 \\
$\mathrm{~T}_{3}$-PET Punnets & 7.32 & 13.26 & 18.46 \\
$\mathrm{~T}_{4}$-HDPE crates $+\mathrm{CaCl}_{2}(2 \%)$ & 7.44 & 12.72 & 17.62 \\
$\mathrm{~T}_{5}$-HDPE crates $+\mathrm{Ca}\left(\mathrm{NO}_{3}\right)_{2}(1.5 \%)$ & 7.82 & 13.55 & 18.91 \\
$\mathrm{~T}_{6}$-HDPE crates & 8.12 & 14.95 & 20.88 \\
$\mathrm{~T}_{7}$-Untreated Control & 13.54 & 23.50 & 32.46 \\
Sem & 0.27 & 0.42 & 0.60 \\
$\mathrm{CD}$ & 0.81 & 1.27 & 1.80 \\
\hline
\end{tabular}

Table 2. Effect of packaging materials and post-harvest calcium treatment on fruit decay of strawberry during storage

\begin{tabular}{|c|c|c|c|}
\hline \multirow{2}{*}{ Treatment } & \multicolumn{3}{|c|}{ Fruit decay (\%) } \\
\hline & 3 DAS & 6 DAS & 8 DAS \\
\hline $\mathrm{T}_{1}$-PET Punnets $+\mathrm{CaCl}_{2}(2 \%)$ & 7.29 & 17.71 & 34.38 \\
\hline $\mathrm{T}_{2}$-PET Punnets $+\mathrm{Ca}\left(\mathrm{NO}_{3}\right)_{2}(1.5 \%)$ & 8.33 & 18.75 & 40.63 \\
\hline $\mathrm{T}_{3}$-PET Punnets & 9.38 & 20.83 & 45.83 \\
\hline $\mathrm{T}_{4}$-HDPE crates $+\mathrm{CaCl}_{2}(2 \%)$ & 9.38 & 19.79 & 39.58 \\
\hline $\mathrm{T}_{5}$-HDPE crates $+\mathrm{Ca}\left(\mathrm{NO}_{3}\right)_{2}(1.5 \%)$ & 10.42 & 21.88 & 42.71 \\
\hline $\mathrm{T}_{6}$-HDPE crates & 11.46 & 22.92 & 47.92 \\
\hline $\mathrm{T}_{7}$-Untreated Control & 25.00 & 62.21 & 91.67 \\
\hline Sem & 0.89 & 1.16 & 1.52 \\
\hline$C D_{(P=0.05)}$ & 2.67 & 3.47 & 4.46 \\
\hline
\end{tabular}

exhibited minimum decay $(7.29 \%)$, followed by fruits treated with $\mathrm{Ca}\left(\mathrm{NO}_{3}\right)_{2} @ 1.5 \%$ and packed in PET Punnets (8.33\%), while the maximum decay (25.00\%) was observed in control. Similar results were was observed at 6 and 8 days of storage, wherein minimum decay loss was observed in the fruits treated $\mathrm{CaCl}_{2}$ $(2 \%)$ and packed in PET Punnets (17.71 and $34.38 \%$, respectively). Untreated control fruit stored at ambient conditions showed far high decay of fruits compared to packaging materials and calcium treated fruits during storage and resulted in maximum decay $(62.21 \%$ and $91.67 \%$ at 6 and 8 days storage, respectively). Packaging materials that regulated the fruit decay loss over the period under different storage conditions might be due to its properties to restrict transpiration from fruit surface and retain a higher level of $\mathrm{CO}_{2}$ inside the packs. Ozkaya et al. (2009) also reported modified atmospheric packaging of strawberry fruits resulted in a lower decay loss than the control fruits (without packaging). High respiration and transpiration rates and also high catabolic process occur and thus, fruits may be affected through severe microbial infection within storage period (Shin et al., 2008). According to López et al. (2007), cinnamon essential oils added into polypropylene (PP) and polyethylene/ethylene (PE/EVOH) films inhibited the growth of spoilage fungi by 4 percent (w/ w). Also, Panda et al. (2016), advocated that LDPE packaging material is effective to control weight loss $(5.49 \%)$ and all of the LDPE films, along with the polypropylene and cling films, are best to minimize decay loss. Packaging material significantly influenced strawberry juice's mass loss (\%) and electrical conductivity $(\mathrm{S} / \mathrm{m})$, irrespective of its interaction with storage conditions and storage durations. It has been reported that fungal growth in strawberry fruit can cause an increase in respiration rate (Bower et al., 2003; HernándezMuñoz et al., 2008); and there is an inverse relationship between respiration rate and shelf-life (Kader, 2002); thus it can be postulated that the decrease in respiration rate by the modified packaging can potentially helpful in minimizing postharvest losses and extending the shelf life of fruits.

\section{Biochemical quality}

A gradual increase in TSS of fruit under all the treatments was noted during storage period (8 days) but there was a non-significant difference among the treatment as noted on 3, 6 and 8 days of storage (Fig. 1A). Fruit TSS at initial was estimated $7.65^{\circ}$ Brix. At 3,6 and 8 days storage highest $\left(8.10,8.36\right.$ and $8.74{ }^{\circ} \mathrm{Brix}$, respectively) was in PET Punnets packaging with $\mathrm{CaCl}_{2}$ $(2 \%)$, followed by in PET Punnets packaging with $\mathrm{Ca}$ 
$\left(\mathrm{NO}_{3}\right)_{2} @ 1.5 \%$ in cold storage while control fruits at ambient condition resulted in minimum TSS $(7.65,7.58$ and 7.18 , respectively). The increase in TSS during storage might be attributed to the increasing concentration of soluble solids in fruit as a result of water loss of fruit and accumulation of soluble sugars with the progression of the storage period. The results of the present study are in close conformity with the findings reported by Sood et al. (2012) in strawberry as they observed that the fruit TSS increased up to $14^{\text {th }}$ day and thereafter decreased in fruits packed in punnets with LDPE cover and treated with $1 \% \mathrm{CaCl}_{2}$. Adams et al. (2017) also observed progressive changes in TSS of banana fruit with the punnet packaging treatments as compared to control. In contrast to TSS, titratable acidity decreased during 8 days storage period in all the treatments (Fig. 1B). The decrease in titratable acidity may be attributed to converting organic acids into sugar and utilising acid in the respiratory process. Packaging and calcium treatments showed a significant effect on acidity. Fruits stored in cold conditions, treated with

(A)
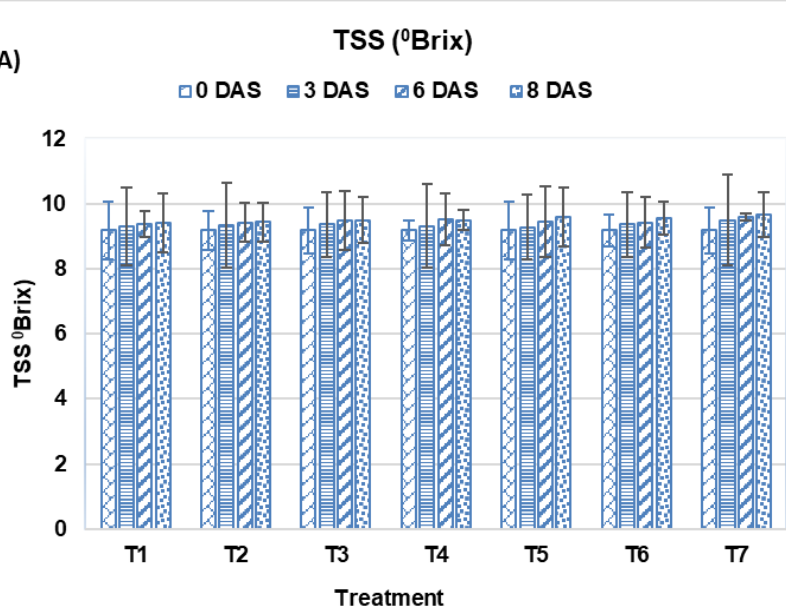

(B)

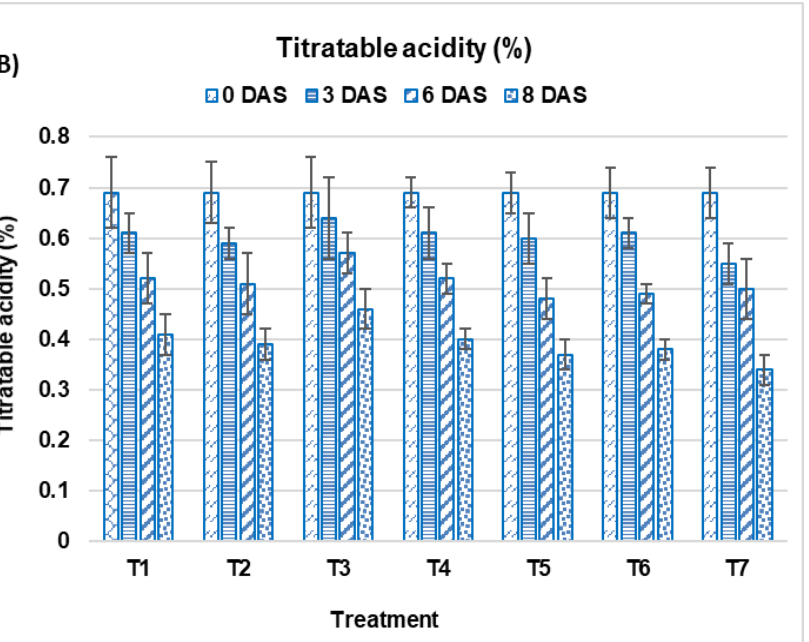

Fig.1. Effect of different packaging materials and calcium compounds on (A) TSS and (B) titratable acidity of strawberry fruit during storage. DAS=Days of storage.
$\mathrm{CaC}_{2}(2 \%)$ and packed in PET Punnets showed maximum titratable acidity, while minimum acidity was noted in untreated control under ambient conditions at 3, 6 and 8 days of storage. The results are in close conformity with the findings of Paraskevopoulou et al. (1995).

The total sugar content of strawberry fruits gradually increased during the storage period (8 days) irrespective of treatments (Fig. 2A). A slight increase of total sugars during storage is due to inhibition of the metabolic process rate after harvest. These findings are in contrast with Upadhayaya and Sanghavi (2001). Although packaging and calcium treatments showed slightly higher total sugars content in fruit in cold storage, the results were statistically at par with TSS of untreated control fruits stored at ambient conditions. The slight increase in total sugar content of stored fruits may be attributed to quick metabolic transformation in the soluble compounds and more conversion of organic acid in to sugar by calcium. These results are in close conformity of the findings reported by Singh et al.
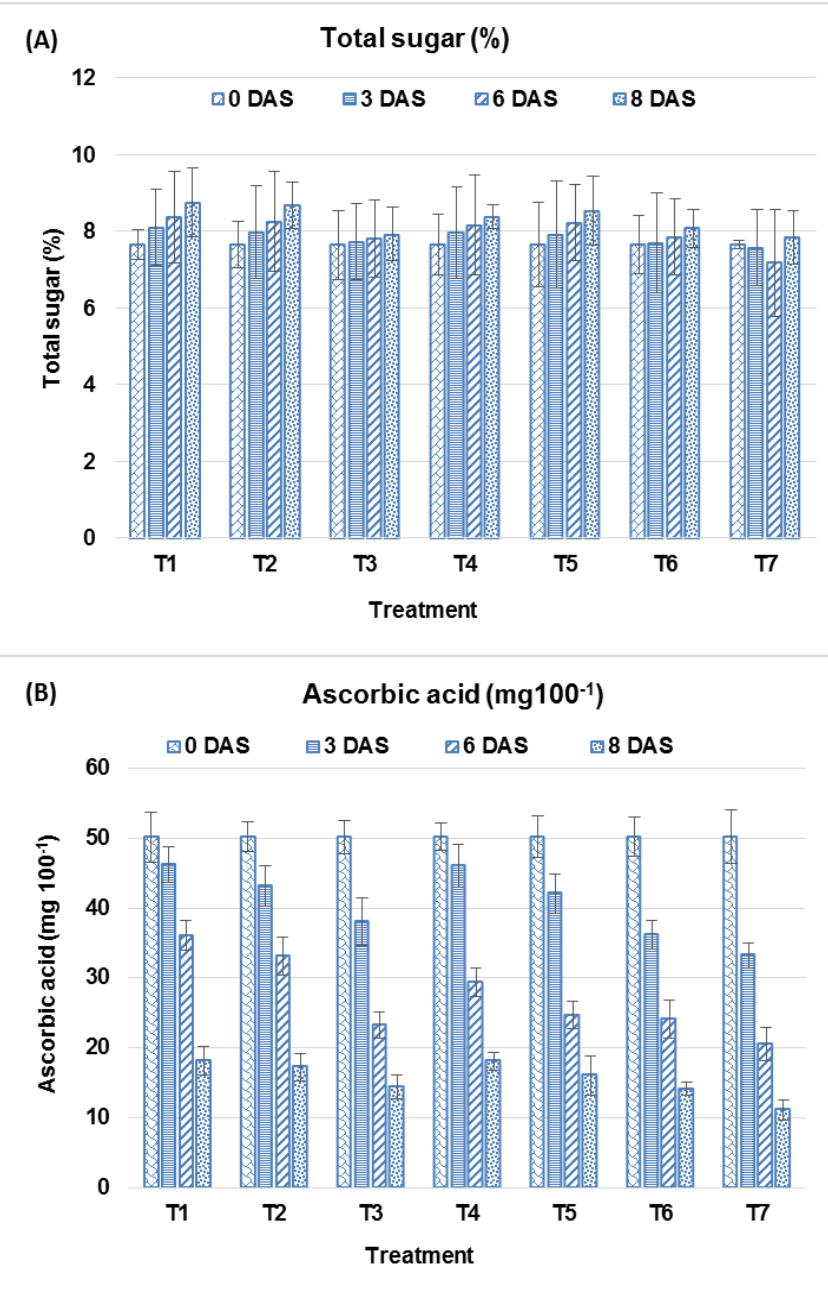

Fig. 2. Effect of different packaging materials and calcium compounds on $(A)$ total sugars and $(B)$ ascorbic acid of strawberry fruit during storage. 
(2008). Irrespective of the packaging treatments, the ascorbic acid content of fruits was decreased during 8 days storage as the ascorbic acid content of fruits was maximum on zero day of storage and the minimum on $8^{\text {th }}$ day of storage (Fig. 2B). Oxidation and irreversible conversion of ascorbic acid to dehydro-ascorbic acid in the presence of enzyme ascorbinase (Kirad et al., 2007 ) is the probable reason for the decrease of ascorbic acid content of fruits with the advancement of days storage duration. Packaging material and calcium treatments significantly influenced the rate of decrease and thus resulted in higher ascorbic acid content in treated fruit stored at cold conditions. PET Punnets packaging with $\mathrm{CaCl}_{2}(2 \%)$ resulted in the highest ascorbic acid

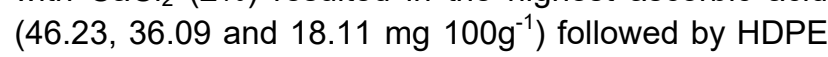
crates with $\mathrm{CaCl}_{2}$ treatments $(46.03,29.34$ and 18.06 $\mathrm{mg} 100 \mathrm{~g}^{-1}$ ) at 3, 6 and 8 days of storage, respectively. Sood et al. (2012) also reported similar results in strawberry. They observed higher ascorbic acid content in the fruits treated with $\mathrm{CaCl}_{2}(1 \%)$ and LDPE covered punnet packaging as compared to untreated control. The effect of packaging materials (plastic punnets, HDPE and polypropiline) may be due to the changes in the atmosphere inside the packaging by reducing the $\mathrm{O}_{2}$ concentration, which at the same time reduced the enzymatic oxidation of ascorbic acid (Agrahari et al., 2001, Panda 2016).

\section{Conclusion}

Packaging material (PET Punnet and HDPE crates) and calcium compound $\left(\mathrm{CaCl}_{2} \& \mathrm{Ca}\left(\mathrm{No}_{3}\right)_{2}\right)$ treatment affected storability and biochemical quality of strawberry fruits (cv. Winter Down) stored in cold conditions $\left(3 \pm 1{ }^{\circ} \mathrm{C}\right)$ as compared with untreated control fruits stored at ambient conations $\left(26^{\circ} \mathrm{C} \pm 3^{\circ} \mathrm{C}\right)$. Fruits treated with $\mathrm{CaCl}_{2}(2 \%)$, packed in polypropylene terephthalate (PET) stored in cold conditions resulted in the most suitable storage treatment for enhancing the storability of fruit by a considerable reduction in the physiological loss in weight and decay per cent and maintain the biochemical quality of fruit. Untreated fruits stored at ambient conditions deteriorated much rapidly than the treated fruits in terms of physiological loss in weight and fruit decay. Therefore, these findings may be useful for producers, stakeholders, and researchers in minimizing physiological loss in weight, fruit decay, and retaining the biochemical quality of strawberry fruit after harvest.

\section{ACKNOWLEDGEMENTS}

The authors wish to express their profound gratitude to Krishi Vigyan Kendra (NHRDF), Ujwa, New Delhi and Amity Institute of Horticulture Studies and Research, Amity University, Noida, for providing the necessary facilities and assistance for carrying out this research.

\section{Conflict of interest}

The authors declare that they have no conflict of interest.

\section{REFERENCES}

1. Association of Official Agricultural Chemists (2019). Official methods of analysis. Association of Official Analytical Chemists, $19^{\text {th }}$ Edn. Washington D.C., USA.

2. Abeles, F.B. \& Takeda, F. (1990). Cellulase activity and ethylene in ripening strawberry and apple fruits. Scientia Horticulturae, 42, 269-275. https://doi.org/10.1016/03044238(90)90050-O.

3. Adams, A., Salifu, A.W., Inusah, L. \& Peter, P. (2017). Modified insulated punnets and conventional packaging films for retail storage of robusta banana fruits. Journal of Scientific Agriculture, 1, 46-53. https://doi.org/10.25081/ jsa.2017.v1i0.29.

4. Agrahari, P.R., Thakur, K.S., Sharma, R.M., Tripathi, V.K. \& Singh, R.R. (2001). Effects of various packaging treatments and storage atmosphere on storage quality of Chandler strawberry (Fragaria $\times$ ananassa Duch.). Scientific Horticulture, 7, 63-74.

5. Ali, A. \& Gaur, G.S. (2013). Effect of organic mulches on runner production of strawberry. Asian Journal of BioScience, 8(2), 175-179.

6. Bower, J.H., Biasi, W.V. \& Mitcham, E.J. (2003). Effects of ethylene and 1-MCP on the quality and storage life of strawberries. Postharvest Biology and Technology, 28, 17 -423. https://doi.org/10.1016/S0925-5214(02)00208-9.

7. Cordenunsi, B.R., Genovese, M.I., Nascimento, J.R.O., Hassimotto, N.M.A., Santos, R.J. \& Lajolo, F.M. (2005). Effects of temperature on the chemical composition and antioxidant activity of three strawberry cultivars. Food Chemistry, 91, 113-121. https://doi.org/10.1016/j.foodch em.2004.05.054.

8. Dunn, J.L. \& Able, A.J., (2006). Pre-harvest calcium effects on sensory quality and calcium mobility in strawberry fruit. Acta Horticulturae. 708, 307-312. https:// doi.org/10.17660/ActaHortic.2006.708.52.

9. Duran, M., Aday, M.S., Zorba, N.N.D., Temizkan, R., Büyükcan, M.B. \& Caner, C. (2016). Potential of antimicrobial active packaging containing natamycin, nisin, pomegranate and grape seed extract in chitosan coating' to extend shelf life of fresh strawberry. Food and Bioproducts Processing, 2016, 98, 354-363. https://doi.org/10.1016/ j.fbp.2016.01.007.

10. El-Kazzaz, M.K., Sommer, N.F. \& Fortlage, R.J. (1983). Effect of different atmospheres on postharvest decay and quality of fresh strawberries. Phytopathology, 73(2), 282285.

11. Garcia, L.C., Pereira, L.M., de Luca Sarantópoulos, C.I.G. \& Hubinger, M.D. (2011). Effect of Antimicrobial Starch Edible Coating on Shelf-Life of Fresh Strawberries. Packaging Technology and Science, 25, 413-425. https:// doi.org/10.1002/pts.987.

12. Garcia, M., Herrera, S. \& Morilla. A. (1996). Effects of postharvest dips in calcium chloride on strawberry. Journal of Agricultural and Food Chemistry, 44, 30-33. https:// 
Kumar, R. et al. / J. Appl. \& Nat. Sci. 13(4), 1158 - 1165 (2021)

doi.org/10.1021/jf950334I.

13. Giampieri, F., Tulipani, S., Alvarez-Suarez, J.M., Quiles, J.L., Mezzetti, B. \& Battino, M. (2012). The strawberry: Composition, nutritional quality, and impact on human health. Nutrition, 28, 9-19. https://doi.org/10.1016/ j.nut.2011.08.009.

14. Gomez, K. A. and Gomez, A. A. (1984). Statistical Procedures for Research Workers, John Willey \& Sons, USA, pp. 8-20.

15. Gorris, L.M. \& Peppelenbos, H.W. (1992). Modified atmosphere and vacuum packaging to extend the shelf life of respiring food products. HortTechnology, 2, 303-309. https://doi.org/10.21273/HORTTECH.2.3.303.

16. Hancock, J.F., Sjuli, T.F. \& Lobos, T.F. (2008). Strawberries. In: Temperate fruit crop breeding-germplasm to genomics, Hancocck, J.F. (Ed.), Springer Science+Business Media, B.V., pp. 393-437.

17. Hernández-Muñoz, P., Almenar, E., Del Valle, V., Vélez, D. \& Gavara, R. (2008). Effect of chitosan coating combined with postharvest calcium treatment on strawberry (Fragaria $\mathrm{x}$ ananassa) quality during refrigerated storage. Food Chemistry, 110, 428-435. https://doi.org/10.1016/ j.foodchem.2008.02.020.

18. Hocking, B., Tyerman, S.D., Burton, R.A. \& Gilliham, M. (2016). Fruit calcium: transport and physiology. Frontiers in Plant Science, 7, 1-17. https://doi.org/10.3389/ fpls.2016.00569.

19. Jouki, M. \& Khazaei, N. (2012). The effect of modified atmosphere packaging and calcium chloride dipping on the quality and shelf life of Kurdistan strawberry, Food Process and Technology, 3(10), 2 -7. https:// doi.org/10.4172/2157-7110.1000184.

20. Kader, A. \& Saltveit, M. (2002). Respiration and gas exchange. In: Postharvest physiology and pathology of vegetables; CRC Press: Boca Raton, FL, USA. https:// doi.org/10.1201/9780203910092.

21. Kader, A.A. (1991). Quality and its maintenance in relation to the postharvest physiology of strawberry. The Strawberry into the $21^{\text {st }}$ Century, Luby, J.J. \& Dale, A. (Eds.). Timber Press, Portland, Oregon. pp. 145-152.

22. Kader, A.A. (1999). Fruit maturity ripening and quality relationships. Proceedings International Symposium on Effect of Pre and Postharvest Factors on Storage of Fruits Acta Horticulturae, 485, 203-208. https://doi.org/10.17660/ ActaHortic.1999.485.27.

23. Kano, Y. \& Asahira, T. (1981). Roles of cytokinin and abscisic acid in the maturing of strawberry fruits. Journal of Japanese Society for Horticultural Science, 50, 31-36. https://doi.org/10.2503/jjshs.50.31.

24. Kirad, K.S., Barche. S., Dash, A. \& Sharma, R.K. (2007). Responses of different packaging materials and chemicals on the shelf life of strawberry (Fragaria $\times$ ananassa Duch.) and correlation between different traits. Acta Horticulturae, 746, 89-95. https://doi.org/10.17660/ActaHortic.20 07.7 46.10.

25. Khalid, S., Majeed, M., Irfan-Ullah, M.I., Shahid, M., Riasat, A.R. Abbas, T., Aatif, H.M., \& Farooq, A. (2020). Effect of storage conditions and packaging material on postharvest quality attributes of strawberry. Journal of Horticulture and Postharvest Research, 3(2), 195-208.

26. López, P., Sánchez, C. Batlle, R. \& Nerín, N. (2007). Development of flexible antimicrobial films using essential oils as active agents. Journal of Agricultural and Food Chemistry, 55(21), 8814-24. https://doi.org/10.1021/jf07 $1737 b$.

27. Matar, C., Guillard, V.,Gauche, G., Costa, S., Gontard, N., Guilbert, S. \& Gaucel, S. (2020). Consumer behaviour in the prediction of postharvest losses reduction for fresh strawberries packed in modified atmosphere packaging. Postharvest Biology and Technology, 163, 111 -119. https://doi.org/10.1016/j.postharvbio.2020.111119.

28. Moyls, A.L., Sholberg, P.L. \& Gaunce, A.P. (1996). Modified-atmosphere packaging of grapes and strawberries fumigated with acetic acid. HortScience, 31(3), 414-416. https://doi.org/10.21273/HORTSCI.31.3.414.

29. Nielsen, T. \& Leufvén, A. (2008). The effect of modified atmosphere packaging on the quality of Honeoye and Korona strawberries. Food Chemistry, 107(3), 1053-1063. https://doi.org/10.1016/j.foodchem.2007.09.025.

30. Olmedo, P., Zepeda, B., Rojas, B., Silva-Sanzana, C., Delgado-Rioseco, J., Fernández, K., Balic, I., Arriagada, C., Moreno, A.A., Defilippi, B.G. \& Campos-Vargas, R. (2021). Cell wall calcium and hemicellulose have a role in the fruit firmness during storage of blueberry (Vacciniu $m$ spp.). Plants, 10(3), 553. https://doi.org/10.33 90/ plants 10030553.

31. Opara, U.L., Caleb, O.J. \& Belay, Z.A. (2019). Modified atmosphere packaging for food preservation, In: Food Quality and Shelf Life, Charis M. Galanakis (Eds.), Academic Press, London, pp. 235-259. https:// doi.org/10.1016/B978-0-12-817190-5.00007-0.

32. Ozkaya, O., Dundar, O., Scovazzo, G.C. \& Volpe, G. (2009). Evaluation of quality parameters of strawberry fruits in modified atmospheric packaging during storage. African Journal of Biotechnology, 8(5), 789-793. https:// www.ajol.info/index.php/ajb/article/view/59961.

33. Panda, A.K., Goyal, R.K., Godara, A.K. \& Sharma, V.K. (2016). Effect of packaging materials on the shelf-life of strawberry cv. Sweet Charlie under room temperature storage. Journal of Applied and Natural Science, 8(3), 1290-1294. https://doi.org/10.31018/jans.v8i3.955.

34. Paniagua, C., Pose, S., Morris, V., Kirby, A., Quesada, M., \& Mercado, J. (2014). Fruit softening and pectin disassembly: An overview of nan-structural pectin modifications assessed by atomic microscopy. Annals of Botany, 114, 1375-1383. https://doi.org/10.1093/aob/mcu149.

35. Paraskevopoulou-Paroussi, G., Vassilakakis, M. \& Dogras, C. (1995). Effect of temperature, duration of cold storage and packaging on post-harvest quality of strawberry fruit. Acta Horticulturae, 379, 337-344. https:// doi.org/10.17660/ActaHortic.1995.379.42.

36. Perkins-Veazie, P. \& Huber, D.J. (1987). Growth and ripening of strawberry fruit under field conditions. Proceedings of the Florida State Horticultural Society, 100, 253256.

37. Perkins-Veazie, P., Huber, D.J. \& Brecht, J.K. (1987). Respiration, ethylene production, and ethylene responsiveness in developing strawberry fruit. Hort Science, 22, 1128.

38. Perkins-Veazie, P.M., Huber, D.J. \& Brecht, J.K. (2008). In vitro growth and ripening of strawberry fruit in the presence of ACC, STS or propylene. Annals of Applied Biology, 128, 105-116. https://doi.org/10.1111/j.1744-7348.199 6.tb07094.x. 
39. Picchioni, G.A., Watada, A.E., Conway, W.S., Whitaker, B. \& Sams, C.E. (1998). Postharvest calcium infiltration delays membrane lipid catabolism in apple fruit. Journal of Agricultural and Food Chemistry, 46, 2452-2457. https:// doi.org/10.1021/jf971083e.

40. Potter, D., Luby, J.J. \& Harrison, R.E. (2000). Phylogenetic relationships among species of Fragaria (Rosaceae) inferred from non-coding nuclear and chloroplast DNA sequences. Systematic Botany, 25, 337-348. https:// doi.org/10.2307/2666646.

41. Pramanick, K.K., Kishore, D.K., Sharma, S.K., Das, B.K. \& Murthy, B.N.S. (2013) Strawberry Cultivation under Diverse Agro-Climatic Conditions of India. International Journal of Fruit Science, 13(1-2), 36-51. https:/l doi.org/10.1080/15538362.2012.696969.

42. Rosen, J.C. \& Kader, A.A. (1989). Postharvest physiology and quality maintenance of sliced pear and strawberry fruits. Journal of Food Technology, 54, 656-659. https:// doi.org/10.1111/j.1365-2621.1989.tb04675.x.

43. Sandhya (2010). Modified atmosphere packaging of fresh produce: Current status and future needs. LWT - Food Science and Technology, 43(3), 381-392. https:// doi.org/10.1016/j.lwt.2009.05.018.

44. Shin, Y., Ryu, J.A., Liu, R.H., Nock, J.F. \& Watkins, C.B. (2008). Harvest maturity, storage temperature and relative humidity affect fruit quality, antioxidant contents and activity, and inhibition of cell proliferation of strawberry fruit. Postharvest Biology and Technology, 49, 201-209. https:// doi.org/10.1016/j.postharvbio.2008.02.008.

45. Singh A, Nath A, Buragohain J \& Deka B C. (2008). Quality and shelf life of strawberry fruits in different packages during storage. Journal Food Science and Technology, 45

\section{(5), 439-42.}

46. Smith, R.B. (1992). Controlled atmosphere storage of 'Redcoat' strawberry fruits. Journal of American Society for Horticultural Science, 117(2), 260-264. https:// doi.org/10.21273/JASHS.117.2.260.

47. Sood, M., Kaul. R.K. \& Sood, P. (2012). Improving strawberry fruit storability by application of post-harvest chemical treatments. Applied Biological Research, 14, 125-130.

48. Tahir, H.E., Zou, X., Jiyong, S., Mahunu, G.K., Zhai, X. \& Mariod, A.A. (2018). Quality and postharvest-shelf life of cold-stored strawberry fruit as affected by gum arabic (Acacia senegal) edible coating. J. Food Biochem., 42(3): e12527. https://doi.org/10.1111/jfbc.12527.

49. Upadhayaya, A.K. \& Sanghavi, K.V. (2001). Effect of various chemical and packaging methods on storage quality of strawberry cv. Chandler. Advances in Plant Science, 14 (2), 343-344.

50. Van-der-Steen, C., Jacxsens, L., Devlieghere, F. \& Debevere, J. (2002). Combining high oxygen atmospheres with low oxygen modified atmosphere packaging to improve the keeping quality of strawberries and raspberries. Postharvest Biology and Technology, 26, 49-58. https://doi.org/10.1016/S0925-5214(02)00005-4.

51. Westwood, M.N. (1979). Temperate Zone Pomology. W.H. Freeman and Company, San Francisco. P. 40.

52. White, P.J. (2001). The pathways of calcium movement to the xylem. Journal of Experimental Botany, 52(358), 891899. https://doi.org/10.1093/jexbot/52.358.891.

53. Wilhelm, S. \& Sagen, J.E. (1974). A history of the strawberry from ancient gardens to modern markets. University of California, Berkeley, CA. 